\title{
МЕТОДИКА
}

УДК 811.111 '42 (07)

DOI: http://dx.doi.org/10.30970/fpl.2018.131.2150

\section{A LINGUISTIC AND DIDACTIC MODEL OF TEACHING ENGLISH RESEARCH ARTICLE WRITING TO DOCTORAL STUDENTS}

\author{
Tatyana Yakhontova
}

\author{
Ivan Franko National University of Lviv, \\ Department of Foreign Languages for Sciences, \\ 41, Doroshenka St., Lviv, Ukraine, 79000, \\ tetyana.yakhontova@lnu.edu.ua
}

\begin{abstract}
Writing for research purposes in English has become extremely important for Ukrainian researchers in view of Ukraine's movement towards European integration and westernization of the country's educational standards. However, the teaching and learning of English research writing requires elaboration and application of specific pedagogical approaches suitable for Ukrainian educational context. This paper revisits and discusses a linguistic and didactic model of teaching English research article writing, the initial variant of which was elaborated twenty years ago and further developed as part of the English for Academic Purposes course for doctoral students majoring in sciences. The model is based upon the concept of genre which provides a holistic vision of various communicative, cognitive and linguistic features of different types of texts. It consists of three major stages with several sub-stages and ensures students' consecutive movement from an introductory stage to a higher level of learning writing. The discussed model has a number of pedagogical advantages as it provides a starting point for writing, possesses a linguistic focus essential for those who learn English outside the immediate sphere of its functioning, and can potentially be used in similar educational contexts.

Keywords: a linguistic and didactic model, genre, genre-based approach to writing, research writing, the English research article, English for Academic Purposes.
\end{abstract}

Introduction. Writing for research purposes in English - this lingua franca of science, technology, and education - has become extremely important for many scholars and researchers worldwide, who experience the pressure to present their findings in English. Publishing in this language has also become a "must" for Ukrainian researchers and educationists in view of Ukraine's movement towards European integration and westernization of the country's educational standards. However, the teaching and learning of English research writing requires elaboration and application of specific pedagogical approaches suitable for Ukrainian educational context.

This paper revisits and discusses a linguistic and didactic model of teaching English research writing, the initial variant of which was elaborated twenty years ago. The model

(C) Yakhontova Tatyana, 2018 
was further developed and expanded as part of the English for Academic Purposes course for graduate students majoring in sciences taught by the author of the paper at the Ivan Franko National University of Lviv within the period of 1998-2018. It is anticipated that the model and experience described in the paper would be of interest for those of Ukrainian university teachers of English who work with doctoral students as well as for their colleagues working in similar contexts. Since the pedagogical model described in the paper is genre-centric, the paper begins with the overview of the concept of genre and its application in writing instruction.

Major concepts of genre and their pedagogical application. Genre concepts have become prominent in a number of fields and have already attracted a considerable attention of linguists and language practitioners. The understanding of what genre is largely depends upon the theoretical framework within which it considered. However, in most general terms, genre can be defined as a certain stereotype, or model of speech behaviour, which is realized through completed texts and possesses three inseparable aspects: communicative, cognitive and verbal (textual). Genres belong to various spheres of life (e.g., the research sphere possesses such genres as articles, monographs, dissertations, conference abstracts, etc.).

Among the theoretical paradigms, within which the notion of genre has appeared to have relevance to pedagogy, four ones deserve special attention. First, it should be noted that all popular genre concepts seem to be related to or stem from the well-known theory of speech genres developed by Russian philosopher and literary scholar Mikhail Bakhtin. According to Bakhtin, genres are relatively stable types of utterances, which are born by the specific goals and circumstances of human communication: "A particular (scientific, technical, commentarial, business, everyday) function and the particular conditions of speech communication specific for each sphere give rise to particular genres" [1, p. 64]. Each genre, Bakhtin stresses, is an inseparable unity of thematic content, style (linguistic choices) and compositional structure. Genres are "mandatory" and free at the same time as they are given to us but, simultaneously, are constantly modified in their textual reproductions. From this Bakhtin makes an extremely important pedagogical conclusion: “... To learn to speak means to learn to construct utterances... The better our command of genres, the more freely we employ them, ... the more perfectly we implement our free speech plan" $[1$, p. 78, 80].

The notion of genre has also been addressed in North American rhetorical tradition, in particular, in the work of C. Miller, author of the seminal paper "Genre as a social action" [8]. According to Miller, genres are sociorhetorical actions which occur in recurrent situations. The author views genres as syntheses of content, form, and context and emphasizes that the study of genres needs to be empirical. Similar to Bakhtin, she comes to a pedagogically relevant conclusion, emphasizing that learning genres means understanding their purposes and communicative contexts.

Within Australian systemic-functional linguistics, genres are also treated as constructs aimed at achieving certain social goals. According to the representatives of this school $[3 ; 7]$, genres are determined by cultural contexts. At the same time, much emphasis is laid on the linguistic aspects of genres, which are considered to be textual phenomena with obligatory and optional features. These features require a thorough linguistic analysis which contributes to the development of genre theory. 
The concept of genre has become prominent in the work of US scholar J. M. Swales, the author of the book "Genre Analysis" [10]. He treats genres as communicative events with a shared set of communicative purposes which constitute the principal criterial feature of any genre. J. M. Swales suggested the procedure of genre analysis based on the consideration of contextual factors and rhetorical moves and steps in a text. This procedure appeared to be extremely valuable for the analysis of specialized texts and has become widespread in the field of English for Specific Purposes.

Current concept of genre provides a holistic vision of various communicative, cognitive and linguistic features of different types of texts. Not surprisingly, its development in the last decade of the previous century has led to the formation of the genre-based approach to writing (see, for example, [6;9]). A genre-based approach can be defined as a methodological framework which focuses on the integrated consideration of various characteristics of a particular genre. Within this approach, learners become aware not only of the structural and linguistic features of the texts in question, but also of their communicative purposes, and develop understanding of social and cultural contexts and factors that influence production and perception of texts. A usual procedure of the genre-based learning of writing includes consideration of the most conspicuous features of the exemplars of the chosen genre, modelling texts and constructing them individually.

A genre-based model of teaching research article writing. A genre-centric approach has already proved its efficiency, especially in teaching writing to non-native speakers of English. One of the first attempts to apply it in Ukrainian educational context was based upon a linguistic and didactic model of teaching English genres of research communication suggested twenty years ago by the author of this paper [12; 13]. The model was built as a practical implementation of Bakhtin's vision of genres as dual, simultaneously static and dynamic, entities. The first stage, or level, of the model was devoted to learning genres as conventional patterns of constructing texts of chosen types, while the second one focused on the creative use of the acquired genre conventions in the process of writing "real" texts. The model has been consistently used in the course of English taught to first-year doctoral students majoring in sciences (mostly applied mathematics, biology, chemistry, and physics) whose level of English knowledge was at least upper-intermediate. The model was primarily utilised for teaching English research article writing. It should be noted that although there exist several types of research articles, one of them seems to be most widespread and important for all researchers. It is a report on the previously conducted research which has a traditional IMRD (Introduction-Method-Results-Discussion) format. The model was used to teaching namely this type of the research article. In the process of application, it was revised and expanded by adding a number of sub-stages at each stage.

Discussion of the revised and expanded model. The application of the model is currently based on the understanding of a multifaceted character of genre knowledge that includes five major aspects $[5 ; 11]$ :

1) sociorhetorical knowledge (social context and purpose of a genre in question, strategies of persuasion in the texts belonging to the genre);

2) process knowledge (procedures through which a genre is realized in texts, including composing processes); 
3) formal knowledge (lexicogrammatical features, structure and composition, modes and media through which the genre can be communicated);

4) subject-matter knowledge, that is specialized knowledge necessary to write on chosen topics;

5) metagenre awareness (understanding of genre concept and of specific genres).

In the suggested model, the acquisition of these aspects of genre (with the exception of subject-matter knowledge which doctoral students already possess or are acquiring in the process of their dissertation writing) is based upon students' consecutive movement from an introductory to a higher level of learning that can be visualised in the following schematic from:

\section{Introductory stage(with two sub-stages) \\ Stage 2: Learning the English research article as a static template \\ Stage 3: Learning the English research article as a creative reproduction of the static template}

This initial model was complemented by two sub-stages and a parallel one in the process of its application in teaching English research writing to Ukrainian doctoral students. The activities within each stage were also modified.

The first, Introductory, stage has been changed several times in the process of the discussed model's application. Currently, it includes two sub-stages, focusing on 1) communicative and contextual aspects and 2) linguistic aspects of the English research article, respectively. The presence of sub-stage 1 in the Introductory stage is partially based upon the assumption formulated by G. Gentil [5], according to which genre knowledge, once acquired in one language, may be used in another language provided there are some common sociocultural expectations as to realizations of genres in both languages. In other words, Ukrainian doctoral students who are generally aware of the structure and conventions of research articles in Ukrainian can use this knowledge in the process of mastering English research article writing.

Sub-stage 1 begins with the discussion of the notion of genre. Such an activity provides a necessary cognitive basis for developing metagenre and metalinguistic awareness of learners, important for success in writing. It should be noted that such an activity is quite appropriate for doctoral students in sciences, the majority of whom are intellectual learners with curious minds able to perceive concepts from the fields other than theirs.

Then the teacher drives the audience towards the consideration of the communicative purposes and sociocognitive context of English research articles, namely, their most popular type - reports on a conducted research. The students are encouraged to use the knowledge acquired in the process of doing research in the Ukrainian educational environment. Usually, they are able to formulate themselves the communicative purposes of the research article but need some additional information to understand the contextual aspects of English research writing. Because of this, it is reasonable to offer students a lecture on the history of the English research article and to explain the role of English in publicizing research findings as well as the importance of writing and publishing in English. 
Sub-stage 1 of the Introductory stage closes with the discussion of the role and major conventions of international journals. The teacher provides some general remarks on the purposes and structure of such journals while the students are asked to take the prominent international journals in their fields and to make short presentations on their editorial policies, requirements to articles and other conspicuous characteristics. Since the groups of doctoral students are usually mixed (consisting of representatives of several fields), there is always a comparison of the journals which makes students deeper think about the role of epistemological and contextual factors in research writing. Overall, the first sub-stage of the introductory stage provides doctoral students with background knowledge necessary for understanding the nature of research article writing.

Sub-stage 2 of the Introductory stage focuses on the linguistic aspects of English research article. This stage is a task-based practice which involves doing various exercises on English academic style standards, such as use of formal vocabulary, noun compounds and collocations typical of research writing in sciences or logical connectors. The students also get acquainted with the Academic Word List (AWL) suggested by A. Coxhead [4]. AWL is a list of highfrequency words used in academic texts. It is a result of corpus linguistic research of English academic journals, textbooks, course workbooks, laboratory manuals and course notes. AWL contains 570 families of words which are regularly used in the texts of major academic fields but are not specific terms. The exercises based on AWL essentially help doctoral students to enrich their vocabulary. At the same time, given the importance of verbs in building sentences, students learn and practise the so-called general scientific verbs [15], that is, formal verbs frequently used in research writing. All these activities are targeted at arming students with linguistic knowledge important for reaching the goals of the course.

Stage 2 of learning English research article writing involves intensive reading, analysis and formal reproduction of important structural parts of articles. This stage begins with discussing dummy texts (genre parodies) that imitate research articles. Dummy texts are quite useful as they usually exaggerate the most conspicuous features of the imitated text and thus focus learner' attention on them. Under the teacher's guidance, students analyse the overall format (IMRD) and rhetorical moves of several dummy texts. As known, the move is a functional textual unit which performs a certain rhetorical function. According to Swales [10], the introductions of English research articles have three moves - Establishing a research territory, Establishing a research niche and Occupying the niche. This sequence of moves (each of them including several steps) reflects the logic of research presentation which begins with showing the importance of the chosen field followed by indication of the need to fill a gap in existing research and announcement of goals or nature of the presented research. The notion of move proved to be extremely helpful in teaching writing as it essentially helps learners to grasp the peculiarities of the functional organization of texts.

It should be noted that dummy texts are, in fact, templates, which, according to Broekhoff, "provide accessible ways for academic learners to generate the sections of a research paper, from a "bottom-up", or inductive perspective; and at the same time to grasp the "moves," or basic sections of a research paper, from a "top-down," or deductive perspective" [2, p. 129].

After discussing the structure and features of dummy texts, students move to analytical reading of authentic English articles in their fields. With the help of the teacher, they analyse 
their overall format, move structure, ways of paragraph development, citation strategies and conspicuous language characteristics. This activity is complemented by relevant exercises from available textbooks on English academic or research writing. The students are also encouraged to compare English research articles with Ukrainian ones, that is, to perform a kind of comparative (or rather contrastive) genre analysis. Such an analysis may involve comparing and/or contrasting the overall structure, moves and separate language features of source (Ukrainian) and target (English) texts. The usefulness of contrastive genre analysis arises from its providing a broader picture of research writing and drawing attention of learners to the issue of cultural influences in communication. At this stage, the teacher can discuss with students several interpretational perspectives on culture in writing, e.g., impact of sociopolitical and sociohistorical circumstances or influence of national intellectual styles or educational traditions.

Also, at this stage students are introduced to the notion of plagiarism and major ways of avoiding it.

Stage 2 of the suggested model closes with the reproductions of the template of the research article in the form of dummy texts which students produce and revise collaboratively and individually. However, all activities at this and the first stage are accompanied by a parallel stage, which envisages participation in an electronic discussion list - a form of written moderated communication, in which each subscribed participant receive all the messages written by other participants. Electronic discussion lists are characterized by informality of communication, nonlinear character of interaction, creation of mutual open textual spaces and blurred distinction between text-producers and text-consumers. Such online discussions (also called online forums) are usually united by a certain topic, often professional. The role of a moderator is played here by a teacher who suggests topics for discussion and encourages the students to participate, that is to express their opinion in English on the offered topic, to agree or disagree with others or to provoke debates. The topics can be quite diverse, ranging, for example, from breakthrough news in sciences to reflexivity on most widespread writing problems. Usually, a minimum participation requirement for a student is established (e. g., five messages per week of approximately 100 words each during four weeks).

The purpose of establishing such a parallel stage is to foster the development of general writing skills in a relaxed atmosphere created in communication between peers. Doctoral students usually like this activity as it allows them to express themselves in English without any situational barriers or language restrictions. As a teaching and learning method, reading and writing through a virtual discussion list has obvious communicative and pedagogical advantages, namely direct and more personal involvement of participants, sharing and borrowing of certain English vocabulary and writing strategies and, very important, relief of strain often caused by writing in a foreign language. All this contributes to faster development of writing skills.

After such preparation, students become ready to produce authentic research articles. At Stage 3, their task is to write a shortened version of a "real" potentially publishable article in English. Such a version can further be expanded depending on publishers' requirements. The students receive a set of criteria allowing them to self-evaluate their work. The criteria concern all the aspects of the research article text, ranging from the structural organization 
of the paper to the use of academic style. The process of writing at this stage is supported by consultations with an English teacher and a dissertation supervisor as well as by peer reviewing of certain parts of texts (e. g., introductions). Finally, students submit their articles to the teacher for final evaluation and grading.

Advantages of the model. The revised and expanded model of teaching English research article writing offers a straightforward and prescriptive teaching of all the constitutive aspects of research articles. This type of teaching seems to be adequate to Ukrainian educational context where the traditions of explicit teaching of research and other forms of writing have never existed (see [14, p. 242-244]). The most obvious advantage of the discussed model consists in providing a general overview of a genre in question - the English research article and, consequently in giving students a starting point for writing. It also has a linguistic focus essential for students in Ukraine who learn English outside the immediate sphere of its functioning. Furthermore, the model is quite understandable for learners due its clearly pragmatic character. Not surprisingly, students have continuously provided a very positive feedback of the course on English research article writing based on this model (the details of the feedback can become a topic of another article).

Conclusions. The described in this article linguistic and didactic model of teaching English research writing is based upon the concept of genre. The choice of this concept as a methodological framework helps to provide learners with a holistic vision of various features of research texts and of the social and cultural contexts in which they are embedded. The future development of the model is related to its potential applicability to teaching research writing in similar educational contexts, e. g., at other Eastern European universities. The model can also be used in teaching other types of professional writing, for example, English business writing or writing in the sphere of information technologies.

\section{REFERENCES}

1. Bakhtin M. Speech Genres and Other Late Essays. Trans. by V. W. McGee / M. Bakhtin. Austin : University of Texas Press, 1986.

2. Broekhoff M. Templates for academic writing / M. Broekhoff. - Nawa Journal of Language and Communication. - 2008. - Vol. 2. - № 2. - P. 129-139.

3. Christie F. Genres as social processes / F. Christie // Working with Genre: Papers from the 1989 LERN Conference. - Leichhardt, NSW : Common Ground, 1991. - P. 73-88.

4. Coxhead A. A new academic word list / A. Coxhead // TESOL Quarterly. - 34(2). - P. 213-238.

5. Gentil G. A biliteracy agenda for genre research / G. Gentil // Journal of Second Language Writing. - 2011. - № 20. - P. 6-23.

6. Hyland K. Genre and Second Language Writing / K. Hyland. - Ann Arbor, MI : Univ. of Michigan Press, 2004. - 248 p.

7. Martin J. R. Social processes in education: A reply to Sawyer and Watson (and others) / J. R. Martin, J. Rothery, F. Christie // The Place of Genre in Learning: Current Debates / ed. by I. Reid. - Geelong : Deakin Univ. Press, 1987. - P. 58-82.

8. Miller C. R. Genre as social action / C. R. Miller // Genre and the New Rhetoric / ed. by A. Freedman, P. Medway. - London : Taylor and Francis, 1994. - P. 23-42.

9. Paltridge B. Genre and the Language Learning Classroom / B. Paltridge. - Ann Arbor, MI : Univ. of Michigan Press, 2004. - 154 p. 
10. Swales J. M. Genre Analysis: English in Academic and Research Settings / J. M. Swales. Cambridge : Cambridge Univ. Press, 1990. - 260 p.

11. Tardy C. M. Building Genre Knowledge / C. Tardy. - West Lafayette, IN: Parlor Press, 2009. - $331 \mathrm{p}$.

12. Yakhontova T. Bakhtin at home and abroad / T. Yakhontova // JAC: A Journal of Composition Theory. - Lawrence, KS, 1997. - Vol. 17. - № 1. - P. 83-94.

13. Yakhontova $T$. The signs of a new time: Academic writing in ESP curricula of Ukrainian universities / T. Yakhontova // Culture and Styles of Academic Discourse. - Berlin : Mouton de Gruyter, 1997. - P. 103-112. - (Trends in Linguistics. Studies and Monographs 104).

14. Yakhontova T. Foreign language writing in Ukraine: Indefinite past but promising future? / T. Yakhontova // Second Language Writing in the Global Context: Represented, Underrepresented, and Unrepresented Voices / ed. By T. Silva, J. Wang, J. Paiz, C. Zhang. - Beijing: Foreign Language Teaching and Research Press, 2016. - P. 239-258.

15. Yakhontova T. V. English Academic Writing for Students and Researchers / T. V. Yakhontova. - Lviv: Ivan Franko National Univ. Press. -220 p.

Стаття надійшла до редколегї 14.10.2018 Прийнята до друку 26.11.2018

\title{
ЛІНГВОДИДАКТИЧНА МОДЕЛЬ НАВЧАННЯ НАПИСАННЮ АНГЛОМОВНИХ НАУКОВИХ СТАТЕЙ ДЛЯ АСПІРАНТІВ
}

\section{Тетяна Яхонтова}

\author{
Львівський національний університет імені Івана Франка, \\ вул. Дорошенка, 41, Львів, Україна, 79000, \\ tetyana.yakhontova@lnu.edu.ua
}

Наголошено, що писати наукові праці англійською мовою важливо для українських дослідників 3 огляду на євроінтеграційні зусилля України та вестернізацію ії освітніх стандартів, однак навчання наукового письма англійською мовою потребує розроблення педагогічних підходів, які можна застосувати в українському освітньому контексті. Розглянуто лінгводидактичну модель підготовки до написання англійських наукових статей, початковий варіант якої був розроблений двадцять років тому і пізніше удосконалений у рамках курсу “Англійська мова для науково-академічних цілей” для аспірантів природничих спеціальностей. Зазначимо, що модель грунтується на концепції жанру, а це сприяє цілісному баченню комунікативних, когнітивних і мовних особливостей різних типів текстів, вона має три основні етапи і забезпечує послідовний рух від початкової стадії до найвищого рівня володіння навиками письма. Доведено, що модель має низку педагогічних переваг, оскільки слугує відправним пунктом для написання статей, має лінгвістичну спрямованість, важливу для тих, хто вивчає англійську мову за межами безпосередньої сфери іiі функціонування, іiї можна потенційно застосовувати в аналогічних освітніх контекстах.

Ключові слова: лінгводидактична модель, жанр, жанровий підхід до навчання письма, наукове письмо, англомовна наукова стаття, англійська мова для науково-академічних цілей. 